\title{
Cataleptic effects of $\mathrm{Y}$-hydroxybutyrate (GHB) and baclofen in mice: mediation by $\mathrm{GABA}_{B}$ receptors, but differential enhancement by $N$-methyl- $d$-aspartate (NMDA) receptor antagonists
}

\author{
Wouter Koek and \\ Department of Psychiatry, The University of Texas Health Science Center at San Antonio, 7703 \\ Floyd Curl Drive, San Antonio, TX 78229-3900, USA. Department of Pharmacology, The \\ University of Texas Health Science Center at San Antonio, San Antonio, TX, USA \\ Charles P. France \\ Department of Psychiatry, The University of Texas Health Science Center at San Antonio, 7703 \\ Floyd Curl Drive, San Antonio, TX 78229-3900, USA. Department of Pharmacology, The \\ University of Texas Health Science Center at San Antonio, San Antonio, TX, USA \\ Wouter Koek: koek@uthscsa.edu
}

\section{Abstract}

Rationale-Gamma-hydroxybutyrate (GHB) is a gamma-aminobutyric acid (GABA) analog that is used to treat narcolepsy but that is also abused. GHB has many actions in common with the $\mathrm{GABA}_{\mathrm{B}}$ receptor agonist baclofen, but their underlying $\mathrm{GABA}_{\mathrm{B}}$ receptor mechanisms may be different.

Objective-The aim of this study is to further investigate a possible differential role of glutamate in $\mathrm{GABA}_{\mathrm{B}}$ receptor-mediated effects of GHB and baclofen.

Materials and methods-The experiments examined the effects of non-competitive antagonists at the $N$-methyl- $d$-asparate (NMDA) subtype of glutamate receptors on GHB-induced catalepsy and compared these effects with those on baclofen-induced catalepsy.

\begin{abstract}
Results-In C57BL/6J mice, ketamine, phencyclidine (PCP), and dizocilpine (MK-801) all enhanced GHB-induced catalepsy. They did so with a potency order (i.e., MK-801 > PCP > ketamine) consistent with their relative potencies as NMDA antagonists but not as inhibitors of dopamine or organic cation transporters. Ketamine, PCP, and MK-801 enhanced catalepsy along inverted U-shaped dose-response curves likely because higher doses affected motor coordination, which limited their catalepsy-enhancing effects. Doses that were maximally effective to enhance GHB-induced catalepsy did not affect the cataleptic effects of baclofen.
\end{abstract}

Conclusions-The finding that NMDA receptor antagonists enhance the cataleptic effects of GHB but not those of baclofen is further evidence that the $\mathrm{GABA}_{B}$ receptor mechanisms mediating the effects of $\mathrm{GHB}$ and $\mathrm{GABA}_{\mathrm{B}}$ agonists are not identical. Differential interactions of glutamate with the $\mathrm{GABA}_{\mathrm{B}}$ receptor mechanisms mediating the effects of GHB and baclofen may explain why GHB is effective for treating narcolepsy and is abused, whereas baclofen is not.

(C) Springer-Verlag 2008

Correspondence to: Wouter Koek, koek@uthscsa. edu. 


\section{Keywords}

Catalepsy; Mice; GHB; Baclofen; GABA-B; MK-801; PCP; Ketamine; NMDA; Glutamate

\section{Introduction}

$\gamma$-Hydroxybutyrate (GHB) is a putative neuromodulator (Maitre 1997) involved in the regulation of sleep (Mamelak et al. 1977) and used clinically to treat narcolepsy in the USA (Tunnicliff and Raess 2002; Fuller and Hornfeldt 2003) and alcoholism in Europe (Poldrugo and Addolorato 1999). GHB is also used recreationally (Rodgers et al. 2004; Gonzalez and Nutt 2005). Its precise mechanism of action is unknown.

GHB binds to $\mathrm{GABA}_{\mathrm{B}}$ receptors (Mathivet et al. 1997; Lingenhoehl et al. 1999) and specific GHB receptors (Benavides et al. 1982; Snead and Liu 1984) in brain that are thought to be involved in the behavioral effects of GHB. At present, there appears to be little evidence for a role for GHB receptors in the in vivo effects of GHB (Wong et al. 2004). Instead, many studies suggest that $\mathrm{GABA}_{\mathrm{B}}$ receptors are particularly important for various behavioral effects of GHB, including discriminative stimulus effects (e.g., Winter 1981, Colombo et al. 1998, Carter et al. 2003, and Koek et al. 2004, 2006), decreased operant responding (Goodwin et al. 2005), and directly observable effects such as hypolocomotion (Kaupmann et al. 2003), catalepsy (Carter et al. 2005), ataxia (Goodwin et al. 2005), and loss of righting (Carai et al. 2001). Consistent with the involvement of $\mathrm{GABA}_{\mathrm{B}}$ receptors, all of these effects of $\mathrm{GHB}$ are produced also by the prototypical $\mathrm{GABA}_{\mathrm{B}}$ receptor agonist baclofen (Carter et al. 2003, 2004, 2005).

Although $\mathrm{GABA}_{\mathrm{B}}$ receptors likely mediate behavioral effects that GHB has in common with baclofen, there is evidence that the underlying $\mathrm{GABA}_{\mathrm{B}}$ receptor mechanisms may not be identical. The $\mathrm{GABA}_{\mathrm{B}}$ receptor antagonist CGP35348 antagonizes the discriminative stimulus effects of GHB and baclofen, consistent with the involvement of $\mathrm{GABA}_{B}$ receptors, but is less potent to antagonize these effects of GHB than those of baclofen (Koek et al. 2004; Carter et al. 2006). Recently, we reported that CGP35348 was also less potent to antagonize the cataleptic effects of GHB and its precursor GBL than those of the GABA receptor agonists baclofen and SKF97541 (Koek et al. 2007b). Together, these findings suggest a possible role for different $\mathrm{GABA}_{B}$ receptor subtypes or different interactions with the same $\mathrm{GABA}_{B}$ receptor in the behavioral effects of GHB and baclofen.

Additional evidence that the $\mathrm{GABA}_{\mathrm{B}}$ receptor mechanisms underlying the effects of GHB and baclofen are not identical has recently been obtained in interaction studies with $N$ methyl- $d$-aspartate (NMDA) receptor antagonists. The NMDA antagonist dizocilpine (MK-801) enhances GHB-induced catalepsy in rats (Sevak et al. 2004, 2005), and GHB and the NMDA antagonist phencyclidine (PCP) enhance each other's discriminative stimulus effects in rats (Koek et al. 2007a). Interestingly, the latter interaction may be specific for GHB because it did not occur with PCP and baclofen (Koek et al. 2007a). The present study is part of an effort to examine the generality of the differential enhancement of behavioral effects of GHB and baclofen by NMDA antagonists. Here, instead of discriminative stimulus effects, the cataleptic effects of GHB and baclofen, which typically occur at higher doses, were examined. GHB- and baclofen-induced catalepsy was studied in animals pretreated with dizocilpine, PCP, or ketamine. Although dizocilpine, PCP, and ketamine are potent antagonists at the NMDA subtype of glutamate receptor, they not only share NMDA antagonist properties but can also produce other effects, such as inhibition of dopamine uptake (e.g., Snell et al. 1988) and, discovered recently, inhibition of organic cation transporters (Amphoux et al. 2006). Thus, to test the hypothesis that NMDA antagonism 
enhances GHB, the present study examined if PCP, dizocilpine, and ketamine enhance the cataleptic effects of GHB with relative potencies that correlate with their NMDA antagonist properties and not with their ability to inhibit dopamine uptake or organic cation transporters.

The present study was conducted in mice to examine the generality of our previous findings in rats. The results show that differential enhancement of GHB and baclofen by NMDA antagonists is not limited to discriminative stimulus effects. Taken together, our studies suggest the possibility that $\mathrm{GABA}_{\mathrm{B}}$ receptors on glutamatergic neurons mediate behavioral effects of $\mathrm{GHB}$, whereas $\mathrm{GABA}_{\mathrm{B}}$ receptors on GABAergic neurons mediate behavioral effects of baclofen. This difference may have implications for their different profiles of preclinical and clinical activities.

\section{Materials and methods}

\section{Animals}

Fifty-seven adult male C57BL/6J mice (The Jackson laboratory, Bar Harbor, ME, USA), weighing $23-34 \mathrm{~g}$ at the beginning of the experiments, were housed in groups of four in an environmentally controlled room (temperature, $24^{\circ} \mathrm{C}$; relative humidity, $45 \%$ ), under a 14:10 h light/dark cycle (light on at 0700 hours), with food (rodent sterilizable diet; Harlan Teklad) and water continuously available. The animals were maintained, and the experiments were conducted in accordance with the Institutional Animal Care and Use Committee, The University of Texas Health Science Center at San Antonio, and with the 1966 Guide for the Care and Use of Laboratory Animals (Institute of Laboratory Animal Resources on Life Sciences, National Research Council, National Academy of Sciences).

\section{Catalepsy}

As described elsewhere (Carter et al. 2005; Koek et al. 2007b), catalepsy was examined using a horizontal cylindrical metal bar (diameter, $1 \mathrm{~cm}$ ) supported $4 \mathrm{~cm}$ above the floor by two $8 \times 8$-cm square pieces of Plexiglas (Instrumentation Services, University of Texas Health Science Center). Mice were tested for catalepsy by placing their forepaws on the bar while the hind paws remain on the floor and then recording the time that both forepaws remained on the bar up to a maximum of $30 \mathrm{~s}$. Each animal received an i.p. injection of saline or of a particular dose of an NMDA antagonist and was tested for catalepsy 15 min later by an observer unaware of the pretreatment condition. Immediately after this test, animals received i.p. injections at 15-min intervals with cumulative doses of GHB (32-320 $\mathrm{mg} / \mathrm{kg}$ ) and were tested for catalepsy at the end of each interval. Each pretreatment was tested in eight mice, except saline control pretreatment, which was tested in 13 mice. Mice were tested repeatedly but not more than 16 times and with at least a week between tests. In an effort to control for repeated testing, pretreatment conditions were tested in a nonsystematic order. To examine the selectivity of the effects on GHB-induced catalepsy, doses of the NMDA antagonists that were maximally effective to enhance GHB were also studied as a pretreatment to cumulative doses of baclofen $(1.78-10 \mathrm{mg} / \mathrm{kg} ; n=8)$.

\section{Ataxia}

Ataxia was studied by means of an inverted screen apparatus (Instrumentation Services, University of Texas Health Science Center) based on that described previously (Coughenour et al. 1977) and consisting of four $13 \times 13-\mathrm{cm}$ wire screens (no. 4 mesh) located $23 \mathrm{~cm}$ above four Plexiglas containers. The four screens were connected to a rod and handle that could be rotated $180^{\circ}$ to simultaneously invert the four screens. Failure to remain on the apparatus for $60 \mathrm{~s}$ after it was rotated was scored as exhibiting ataxia. Animals received an i.p. injection of 
saline or a particular dose of an NMDA antagonist $(n=4)$ and, 15 min later, were examined for ataxia.

\section{Data analysis}

For each pretreatment drug and dose, the area under the treatment drug dose-effect curve (AUC) was calculated for each animal by means of GraphPad Prism version 4.03 for Windows (GraphPad Software, San Diego, CA, USA). Because the same treatment drug doses were used throughout, the AUC offered a measure of the effectiveness of the treatment drug under various pretreatment conditions. Pretreatment drug effects on the individual AUC values for GHB and, on the time the forepaws remained on the bar when the pretreatment was given alone, were analyzed by one-way analysis of variance (ANOVA) followed by Dunnett's test (GraphPad Prism). Effects of pretreatment drugs on AUC values for baclofen were analyzed by Student's $t$ test (GraphPad Prism). Relations between the potency of pretreatment drugs to affect AUC values and to produce other previously reported effects were examined by calculating Pearson's correlation coefficient using logtransformed potency values.

Daily administration of a relatively high $(200 \mathrm{mg} / \mathrm{kg}$ ) dose of GHB during 14 days has been reported to produce tolerance to its cataleptic effects in mice (Itzhak and Ali 2002). In the present study, drug doses were tested in a non-systematic order, with at least 1 week between tests. In an effort to examine possible effects of repeated testing under the conditions of the present study, the dose-response data of the GHB experiments were analyzed by dividing the data at each dose into two groups based on whether they were obtained earlier or later in the study. Two-way ANOVA followed by Bonferroni post-tests (GraphPad Prism) were used to compare dose-response data obtained earlier and later in the study.

Drug effects on ataxia were analyzed by comparing the percentage of drug-treated animals showing ataxia with the percentage of saline-treated controls showing ataxia by means of Fisher's exact test (GraphPad Prism). Correlations were quantified by Pearson's correlation coefficient.

\section{Drugs}

$\gamma$-Hydroxybutyrate sodium (GHB) and ( \pm )baclofen were purchased from Sigma-Aldrich (USA), ketamine hydrochloride from Fort Dodge Laboratories (Fort Dodge, IA, USA), and dizocilpine from Research Biochemicals International (Natick, MA, USA). Phencyclidine was obtained from NIDA (Research Technology Branch, Rockville, MD, USA). All compounds were dissolved in physiological saline $(0.9 \% \mathrm{NaCl})$, except $\mathrm{GHB}$, which was dissolved in sterile water. All compounds were injected i.p. in a volume of 5 to $20 \mathrm{ml} / \mathrm{kg}$. Doses are expressed as the form of the compound listed above.

\section{Results}

Neither ketamine nor PCP produced catalepsy in C57BL/6J mice when given alone (Fig. 1a). Pretreatment with either drug did not significantly affect the mean time that both forepaws remained on the bar (ketamine, $F[5,47]=2.28, P>0.05$; PCP, $F[4,44]=1.02$, $P>0.20)$. However, dizocilpine significantly $(F[4,44]=14.63, P<0.001)$ affected this measure in a biphasic manner, increasing the time the forepaws remained on the bar at a dose of $0.178 \mathrm{mg} / \mathrm{kg}$ and decreasing it at $0.32 \mathrm{mg} / \mathrm{kg}$.

In animals pretreated with saline, GHB and baclofen dose-dependently produced catalepsy (Fig. 1b, c; solid circles). Ketamine, PCP, and dizocilpine enhanced the cataleptic effects of GHB (Fig. 1b) and significantly increased the AUC values for GHB (Fig. 1d, solid circles; 
$F[5,47]=7.0, P<0.001, F[4,44]=4.78, P<0.005$, and $F[4,44]=20.71, P<0.001$, respectively; AUC values obtained earlier and later in the study were not significantly different, assessed by ANOVA and post-tests). Ketamine, PCP, and dizocilpine significantly and maximally increased the AUC values for GHB at $17.8,5.6$, and $0.178 \mathrm{mg} / \mathrm{kg}$, respectively. At these doses, none of the NMDA antagonists significantly altered the cataleptic effects of baclofen (Fig. 1c) measured as area under the curve (Fig. 1d; open circles; $t \unlhd 0.64, d f=18, P \searrow 0.50$ ). At higher doses that no longer enhanced GHB-induced catalepsy (i.e., $100 \mathrm{mg} / \mathrm{kg}$ ketamine, 10 $\mathrm{mg} / \mathrm{kg}$ PCP, $0.32 \mathrm{mg} / \mathrm{kg}$ dizocilpine), all three NMDA antagonists produced ataxia in $100 \%$ of the animals tested, compared with $0 \%$ ataxia in saline-treated animals $(P<0.05$; data not shown).

The relative potencies with which ketamine, PCP, and dizocipline enhanced the cataleptic effects of GHB correlated positively and strongly $(r=0.99)$ with their potency to antagonize NMDA-induced convulsions (Fig. 2a) and with their potency to inhibit binding of the PCP derivative thienylcyclohexyl piperidine (TCP) at the NMDA receptor-associated ion channel (Fig. 2b). In contrast, the catalepsy-enhancing effects of ketamine, PCP, and dizocilpine correlated only weakly and negatively with their potency to inhibit dopamine and organic cation transporters (Fig. 2c, d; $1=-0.45$ and -0.20 , respectively). The doses at which the NMDA antagonists enhanced GHB-induced catalepsy were 4- to 16-fold lower than those reported (Koek and Colpaert 1990) to block NMDA-induced convulsions (Fig. 2a) and were very similar to those reported (Maurice and Vignon 1990) to inhibit TCP-binding in vivo (Fig. 2b).

\section{Discussion}

The main finding of this study is that GHB-induced catalepsy was selectively enhanced by dizocilpine, PCP, and ketamine, with a potency order (i.e., dizocilpine $>\mathrm{PCP}>$ ketamine, based on their minimum effective dose: $0.178,3.2$, and $17.8 \mathrm{mg} / \mathrm{kg}$, respectively) similar to their relative potencies to antagonize effects of NMDA in vivo (e.g., Koek et al. 1990) and consistent with their relative affinities at binding sites in the ion channel of the NMDA receptor complex labeled with PCP (e.g., Wong et al. 1988) or the PCP derivative, TCP (e.g., Maurice and Vignon 1990). Dizocilpine significantly increased catalepsy when given alone. It is unlikely that NMDA antagonism is involved in these effects of dizocilpine because neither PCP nor ketamine produced catalepsy when given alone. Whichever the mechanism, this dose of dizocilpine did not generally enhance the cataleptic effects of other drugs but selectively enhanced GHB-induced catalepsy as did the other NMDA antagonists PCP and ketamine. The present results in mice (1) are consistent with previous findings that dizocilpine enhances GHB-induced catalepsy in rats (Sevak et al. 2004, 2005), (2) extend them to other channel-blocking NMDA antagonists, (3) show that their catalepsy-enhancing effects correlate positively with their NMDA antagonist properties instead of with their dopamine or organic cation transporter blocking effects, and (4) suggest that their catalepsyenhancing effects are selective for GHB. The latter finding is consistent with evidence that PCP and GHB enhance each other's discriminative stimulus effects, but PCP and baclofen do not (Koek et al. 2007a). Taken together, these findings are further evidence that the $\mathrm{GABA}_{\mathrm{B}}$ receptor mechanisms mediating the effects of GHB and baclofen are not identical (e.g., Koek et al. 2007b), and suggest that these $\mathrm{GABA}_{\mathrm{B}}$ receptor mechanisms are differentially modulated by glutamatergic systems.

Baclofen produces catalepsy in rats after peripheral (i.p.; Mehta and Ticku 1987) and central (ventromedial thalamic nucleus; Wullner et al. 1987) administration, likely related to its effects on striatal dopamine synthesis, which are similar to those of the neuroleptic haloperidol (Waldmeier 1991). However, these neurochemical effects of baclofen are mediated by $\mathrm{GABA}_{\mathrm{B}}$ receptors, unlike those of haloperidol (Waldmeier 1991). Consistent 
with the involvement of $\mathrm{GABA}_{\mathrm{B}}$ receptors, baclofen-induced catalepsy is blocked by the $\mathrm{GABA}_{\mathrm{B}}$ receptor antagonist $\delta$-aminovalericacid and not by bicuculline, bromocriptine, or scopolamine (Mehta and Ticku 1987). In the present study, catalepsy was produced by

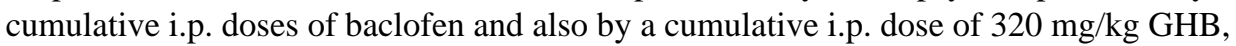
consistent with previous reports of catalepsy following $560 \mathrm{mg} / \mathrm{kg}$ GHB i.p. in SpraqueDawley rats (Sevak et al. 2004), $200 \mathrm{mg} / \mathrm{kg}$ GHB i.p. in OF.1 mice (Navarro et al. 1998), $300 \mathrm{mg} / \mathrm{kg}$ GHB i.p. in Swiss-Webster mice (Itzhak and Ali 2002), and $320 \mathrm{mg} / \mathrm{kg}$ GHB i.p. in C57BL/6J mice (Carter et al. 2005; Koek et al. 2007b), the same strain as used in the present study. The lowest dose of GHB and baclofen that produced near-maximal catalepsy in the cumulative dosing procedure used here (i.e., 320 and $10 \mathrm{mg} / \mathrm{kg}$ i.p., respectively) was the same as in the single dosing procedure used previously (Carter et al. 2005; Koek et al. 2007b), suggesting that, under the conditions of these experiments, the potency of GHB and baclofen to produce catalepsy in C57BL/6J mice is not markedly affected by the use of single or cumulative dosing. The observation that GHB, which has agonist activity at $\mathrm{GABA}_{\mathrm{B}}$ receptors (Lingenhoehl et al. 1999), has cataleptic effects in common with a wellcharacterized $\mathrm{GABA}_{\mathrm{B}}$ receptor agonist and the finding that these effects can be blocked by the $\mathrm{GABA}_{\mathrm{B}}$ receptor antagonist CGP35348 (e.g., Koek et al. 2007b) are further evidence that $\mathrm{GABA}_{\mathrm{B}}$ receptors are involved in GHB-induced catalepsy.

Although $\mathrm{GABA}_{\mathrm{B}}$ receptors appear to be involved, the $\mathrm{GABA}_{\mathrm{B}}$ receptor mechanisms underlying the effects of GHB and baclofen may not be identical. For example, the $\mathrm{GABA}_{B}$ receptor antagonist CGP35348 attenuated GHB-and baclofen-induced catalepsy, demonstrating a role for $\mathrm{GABA}_{\mathrm{B}}$ receptors, but was threefold less potent to antagonize the effects of GHB than those of baclofen, suggesting differential involvement of $\mathrm{GABA}_{B}$ receptors in the cataleptic effects of GHB and baclofen (Koek et al. 2007b). Furthermore, PCP and GHB enhance each other's discriminative stimulus effects, but PCP and baclofen do not (Koek et al. 2007a), suggesting that the mechanisms underlying these effects of GHB and baclofen are differentially modulated by the glutamatergic systems with which PCP interacts (Koek et al. 2007a). The present finding that PCP and other antagonists at the NMDA subtype of glutamate receptors enhance the cataleptic effects of GHB but not those of baclofen suggests that differential modulation by glutamate of the $\mathrm{GABA}_{\mathrm{B}}$ systems underlying the effects of GHB and baclofen may have considerable generality.

Recent electrophysiological studies offer additional evidence of differing effects of GHB and baclofen. When applied at clinically relevant concentrations, GHB disinhibits and baclofen inhibits ventral tegmental dopamine neurons (Cruz et al. 2004). This suggests that GHB would be more likely than baclofen to activate the dopamine system implicated in addiction and that baclofen, which may be useful to reduce relapse to cocaine-taking (e.g., Weerts et al. 2007), may have more pronounced anti-craving effects than GHB (Cruz et al. 2004). GHB and baclofen also differ in their effects on excitatory neuro-transmission at NMDA and a-amino-3-hydroxy-5-methyl-4-isoxazole-propionic acid (AMPA) subtypes of glutamate receptors in neocortex ( $\mathrm{Li}$ et al. 2007). Both GHB and baclofen inhibited excitatory postsynaptic currents elicited by NMDA and AMPA, and these effects could be reversed by the selective $\mathrm{GABA}_{\mathrm{B}}$ receptor antagonist CGP62349. Interestingly, GHB more potently depressed NMDA receptor-mediated postsynaptic currents, whereas baclofen more potently depressed responses mediated by the AMPA subtype of glutamate receptors ( $\mathrm{Li}$ et al. 2007). These latter findings, together with the present results, suggest a special role for NMDA receptors in the $\mathrm{GABA}_{\mathrm{B}}$ receptor-mediated effects of GHB. Thus, there is emerging evidence that the effects of GHB and baclofen, although in many respects similar, may be mediated by different $\mathrm{GABA}_{\mathrm{B}}$ systems.

There is evidence for functional $\mathrm{GABA}_{\mathrm{B}}$ receptor subtypes (Seabrook et al. 1990; Bonanno and Raiteri 1992; Lanza et al. 1993; Fassio et al. 1994; Yamada et al. 1999). Conceivably, 
differential activity of GHB and baclofen at $\mathrm{GABA}_{\mathrm{B}}$ autoreceptors and heteroreceptors could account for the differential ability of CGP35348 to antagonize GHB and baclofen. Alternatively, GHB and baclofen may interact differently with the same $\mathrm{GABA}_{\mathrm{B}}$ receptor (e.g., GHB may induce conformational changes in the $\mathrm{GABA}_{\mathrm{B}}$ receptor that differ from those induced by baclofen). Differential activity of GHB and baclofen at auto- and heteroreceptors could also account for the differential enhancement of their effects by antagonists at the NMDA subtype of glutamate receptor observed in the present study, with effects of GHB mediated by glutamatergic $\mathrm{GABA}_{B}$ heteroreceptors and effects of baclofen by $G_{A B A}$ autoreceptors. Further studies examining the different $G_{A B} A_{B}$ mechanisms underlying effects of GHB and baclofen may help to explain why GHB is effective to treat narcolepsy and is abused, whereas there is no evidence that baclofen is effective in any sleep disorder and no evidence that baclofen is abused.

\section{Acknowledgments}

The work was supported by the US Public Health Service Grants DA15692 (W.K.) and DA17918 (C.P.F.)

The authors thank Adela Garza and Jason Persyn for technical assistance. The work was supported by the US Public Health Service Grants DA15692 (W.K.) and DA17918 (C.P.F.).

\section{References}

Amphoux A, Vialou V, Drescher E, Brüss M, Mannoury La Cour C, Rochat C, Millan MJ, Giros B, Bönisch H, Gautron S. Differential pharmacological in vitro properties of organic cation transporters and regional distribution in rat brain. Neuropharmacology. 2006; 50:941-952. [PubMed: 16581093]

Benavides J, Rumigny JF, Bourguignon JJ, Cash C, Wermuth CG, Mandel P, Vincendon G, Maitre M. High affinity binding sites for gamma-hydroxybutyric acid in rat brain. Life Sci. 1982; 30:953-961. [PubMed: 7070203]

Bonanno G, Raiteri M. Functional evidence for multiple gamma-aminobutyric acid B receptor subtypes in the rat cerebral cortex. J Pharmacol Exp Ther. 1992; 262:114-118. [PubMed: 1352547]

Carai MA, Colombo G, Brunetti G, Melis S, Serra S, Vacca G, Mastinu S, Pistuddi AM, Solinas C, Cignarella G, Minardi G, Gessa GL. Role of GABA(B) receptors in the sedative/hypnotic effect of gamma-hydroxybutyric acid. Eur J Pharmacol. 2001; 428:315-321. [PubMed: 11689189]

Carter LP, Flores LR, Wu H, Chen W, Unzeitig AW, Coop A, France CP. The role of GABAB receptors in the discriminative stimulus effects of gamma-hydroxybutyrate in rats: time course and antagonism studies. J Pharmacol Exp Ther. 2003; 305:668-674. [PubMed: 12606639]

Carter LP, Wu H, Chen W, Cruz CM, Lamb RJ, Koek W, Coop A, France CP. Effects of gammahydroxybutyrate $(\mathrm{GHB})$ on schedule-controlled responding in rats: role of GHB and GABAB receptors. J Pharmacol Exp Ther. 2004; 308:182-188. [PubMed: 14569056]

Carter LP, Wu H, Chen W, Matthews MM, Mehta AK, Hernandez RJ, Thomson JA, Ticku MK, Coop A, Koek W, France CP. Novel \{gamma\}-hydroxybutyric acid (GHB) analogs share some, but not all, of the behavioral effects of GHB and GABAB receptor agonists. J Pharmacol Exp Ther. 2005; 313:1314-1323. [PubMed: 15769868]

Carter LP, Chen W, Coop A, Koek W, France CP. Discriminative stimulus effects of GHB and GABA(B) agonists are differentially attenuated by CGP35348. Eur J Pharmacol. 2006; 538:85-93. [PubMed: 16647701]

Colombo G, Agabio R, Lobina C, Reali R, Gessa GL. Involvement of GABA(A) and GABA(B) receptors in the mediation of discriminative stimulus effects of gamma-hydroxybutyric acid. Physiol Behav. 1998; 64:293-302. [PubMed: 9748096]

Coughenour LL, Mclean JR, Parker RB. A new device for the rapid measurement of impaired motor function in mice. Pharmacol Biochem Behav. 1977; 6:351-353. [PubMed: 857257]

Cruz HG, Ivanova T, Lunn ML, Stoffel M, Slesinger PA, Lüscher C. Bi-directional effects of GABA(B) receptor agonists on the mesolimbic dopamine system. Nat Neurosci. 2004; 7:153-159. [PubMed: 14745451] 
Fassio A, Bonanno G, Cavazzani P, Raiteri M. Characterization of the GABA autoreceptor in human neocortex as a pharmacological subtype of the GABAB receptor. Eur J Pharmacol. 1994; 263:311-314. [PubMed: 7843269]

Fuller DE, Hornfeldt CS. From club drug to orphan drug: sodium oxybate (Xyrem) for the treatment of cataplexy. Pharmacotherapy. 2003; 23:1205-1209. [PubMed: 14524654]

Gonzalez A, Nutt DJ. Gamma hydroxy butyrate abuse and dependency. J Psychopharmacol. 2005; 19:195-204. [PubMed: 15871147]

Goodwin AK, Froestl W, Weerts EM. Involvement of gamma-hydroxybutyrate (GHB) and GABA-B receptors in the acute behavioral effects of GHB in baboons. Psychopharmacology (Berl). 2005; 180:342-351. [PubMed: 15739078]

Itzhak Y, Ali SF. Repeated administration of gamma-hydroxybutyric acid (GHB) to mice: assessment of the sedative and rewarding effects of GHB. Ann N Y Acad Sci. 2002; 965:451-460. [PubMed: 12105120]

Johnson KM, Snell LD. Effects of phencyclidine (PCP)-like drugs on turning behavior, 3H-dopamine uptake, and 3H-PCP binding. Pharmacol Biochem Behav. 1985; 22:731-735. [PubMed: 2989942]

Kaupmann K, Cryan JF, Wellendorph P, Mombereau C, Sansig G, Klebs K, Schmutz M, Froestl W, van der PH, Mosbacher J, Brauner-Osborne H, Waldmeier P, Bettler B. Specific gammahydroxybutyrate-binding sites but loss of pharmacological effects of gamma-hydroxybutyrate in GABA(B)(1)-deficient mice. Eur J Neurosci. 2003; 18:2722-2730. [PubMed: 14656321]

Koek W, Colpaert FC. Selective blockade of $N$-methyl- $d$-aspartate (NMDA)-induced convulsions by NMDA antagonists and putative glycine antagonists: relationship with phencyclidine-like behavioral effects. J Pharmacol Exp Ther. 1990; 252:349-357. [PubMed: 2153806]

Koek W, Woods JH, Colpaert FC. $N$-Methyl- $d$-aspartate antagonism and phencyclidine-like activity: a drug discrimination analysis. J Pharmacol Exp Ther. 1990; 253:1017-1025. [PubMed: 2193142]

Koek W, Flores LR, Carter LP, Lamb RJ, Chen W, Wu H, Coop A, France CP. Discriminative stimulus effects of gamma-hydroxybutyrate in pigeons: role of diazepam-sensitive and -insensitive GABA(A) and GABA(B) receptors. J Pharmacol Exp Ther. 2004; 308:904-911. [PubMed: 14718595]

Koek W, Wu H, Coop A, France CP. Discriminative stimulus effects of gamma-hydroxybutyrate: role of training dose. J Pharmacol Exp Ther. 2006; 317:1-9. [PubMed: 16322354]

Koek W, Khanal M, France CP. Synergistic interactions between 'club drugs': gammahydroxybutyrate and phencyclidine enhance each other's discriminative stimulus effects. Behav Pharmacol. 2007a; 18:807-810. [PubMed: 17989519]

Koek W, Mercer SL, Coop A. Cataleptic effects of g-hydroxybutyrate (GHB), its precursor gbutyrolactone (GBL), and GABAB receptor agonists in mice: differential antagonism by the GABAB receptor antagonist CGP35348. Psychopharmacology. 2007b; 192:407-414. [PubMed: 17277933]

Lanza M, Fassio A, Gemignani A, Bonanno G, Raiteri M. CGP 52432: a novel potent and selective GABAB autoreceptor antagonist in rat cerebral cortex. Eur J Pharmacol. 1993; 237:191-195. [PubMed: 8103461]

Li Q, Kuhn CM, Wilson WA, Lewis DV. Effects of gamma hydroxybutyric acid on inhibition and excitation in rat neocortex. Neuroscience. 2007; 150:82-92. [PubMed: 17904295]

Lingenhoehl K, Brom R, Heid J, Beck P, Froestl W, Kaupmann K, Bettler B, Mosbacher J. Gammahydroxybutyrate is a weak agonist at recombinant GABA(B) receptors. Neuropharmacology. 1999; 38:1667-1673. [PubMed: 10587082]

Maitre M. The gamma-hydroxybutyrate signalling system in brain: organization and functional implications. Prog Neurobiol. 1997; 51:337-361. [PubMed: 9089792]

Mamelak M, Escriu JM, Stokan O. The effects of gamma-hydroxybutyrate on sleep. Biol Psychiatry. 1977; 12:273-288. [PubMed: 192353]

Mathivet P, Bernasconi R, De BJ, Marescaux C, Bittiger H. Binding characteristics of gammahydroxybutyric acid as a weak but selective GABAB receptor agonist. Eur J Pharmacol. 1997; 321:67-75. [PubMed: 9083788]

Maurice T, Vignon J. In vivo labeling of phencyclidine (PCP) receptors with $3 \mathrm{H}-\mathrm{TCP}$ in the mouse brain. J Neurosci Res. 1990; 26:377-385. [PubMed: 2168951] 
Mehta AK, Ticku MK. Baclofen induces catatonia in rats. Neuropharmacology. 1987; 26:1419-1423. [PubMed: 2823166]

Navarro JF, Pedraza C, Martin M, Manzaneque JM, Davila G, Maldonado E. Tiapride-induced catalepsy is potentiated by gamma-hydroxybutyric acid administration. Prog Neuropsychopharmacol Biol Psychiatry. 1998; 22:835-844. [PubMed: 9723123]

Poldrugo F, Addolorato G. The role of gamma-hydroxybutyric acid in the treatment of alcoholism: from animal to clinical studies. Alcohol Alcohol. 1999; 34:15-24. [PubMed: 10075397]

Rodgers J, Ashton CH, Gilvarry E, Young AH. Liquid ecstasy: a new kid on the dance floor. Br J Psychiatry. 2004; 184:104-106. [PubMed: 14754820]

Seabrook GR, Howson W, Lacey MG. Electrophysiological characterization of potent agonists and antagonists at pre- and postsynaptic $\mathrm{GABAB}$ receptors on neurones in rat brain slices. $\mathrm{Br} \mathrm{J}$ Pharmacol. 1990; 101:949-957. [PubMed: 1964824]

Sevak RJ, France CP, Koek W. Neuroleptic-like effects of gamma-hydroxybutyrate: interactions with haloperidol and dizocilpine. Eur J Pharmacol. 2004; 483:289-293. [PubMed: 14729119]

Sevak RJ, Koek W, France CP. Streptozotocin-induced diabetes differentially modifies haloperidoland gamma-hydroxybutyric acid (GHB)-induced catalepsy. Eur J Pharmacol. 2005; 517:64-67. [PubMed: 15975572]

Snead OC III, Liu CC. Gamma-hydroxybutyric acid binding sites in rat and human brain synaptosomal membranes. Biochem Pharmacol. 1984; 33:2587-2590. [PubMed: 6087835]

Snell LD, Yi SJ, Johnson KM. Comparison of the effects of MK-801 and phencyclidine on catecholamine uptake and NMDA-induced norepinephrine release. Eur J Pharmacol. 1988; 145:223-226. [PubMed: 3280329]

Tunnicliff G, Raess BU. Gamma-hydroxybutyrate (orphan medical). Curr Opin Investig Drugs. 2002; 3:278-283.

Waldmeier PC. The GABAB antagonist, CGP 35348, antagonizes the effects of baclofen, gammabutyrolactone and HA 966 on rat striatal dopamine synthesis. Naunyn-Schmiedebergs Arch Pharmacol. 1991; 343:173-178. [PubMed: 1648673]

Weerts EM, Froestl W, Kaminski BJ, Griffiths RR. Attenuation of cocaine-seeking by GABA B receptor agonists baclofen and CGP44532 but not the GABA reuptake inhibitor tiagabine in baboons. Drug Alcohol Depend. 2007; 89:206-13. [PubMed: 17234367]

Winter JC. The stimulus properties of gamma-hydroxybutyrate. Psychopharmacology (Berl). 1981; 73:372-375. [PubMed: 6789360]

Wong EHF, Knight AR, Woodruff GN. (3H)MK-801 labels a site on the $N$-methyl- $d$-asparate receptor channel complex in rat brain membranes. J Neurochem. 1988; 50:274-281. [PubMed: 2826686]

Wong CG, Gibson KM, Snead OC III. From the street to the brain: neurobiology of the recreational drug gamma-hydroxybutyric acid. Trends Pharmacol Sci. 2004; 25:29-34. [PubMed: 14723976]

Wullner U, Klockgether T, Schwarz M, Sontag KH. Behavioral actions of baclofen in the rat ventromedial thalamic nucleus: antagonism by delta-aminovalerate. Brain Res. 1987; 422:129_ 136. [PubMed: 3676775]

Yamada K, Yu B, Gallagher JP. Different subtypes of GABAB receptors are present at pre- and postsynaptic sites within the rat dorsolateral septal nucleus. J Neurophysiol. 1999; 81:2875-2883. [PubMed: 10368404] 

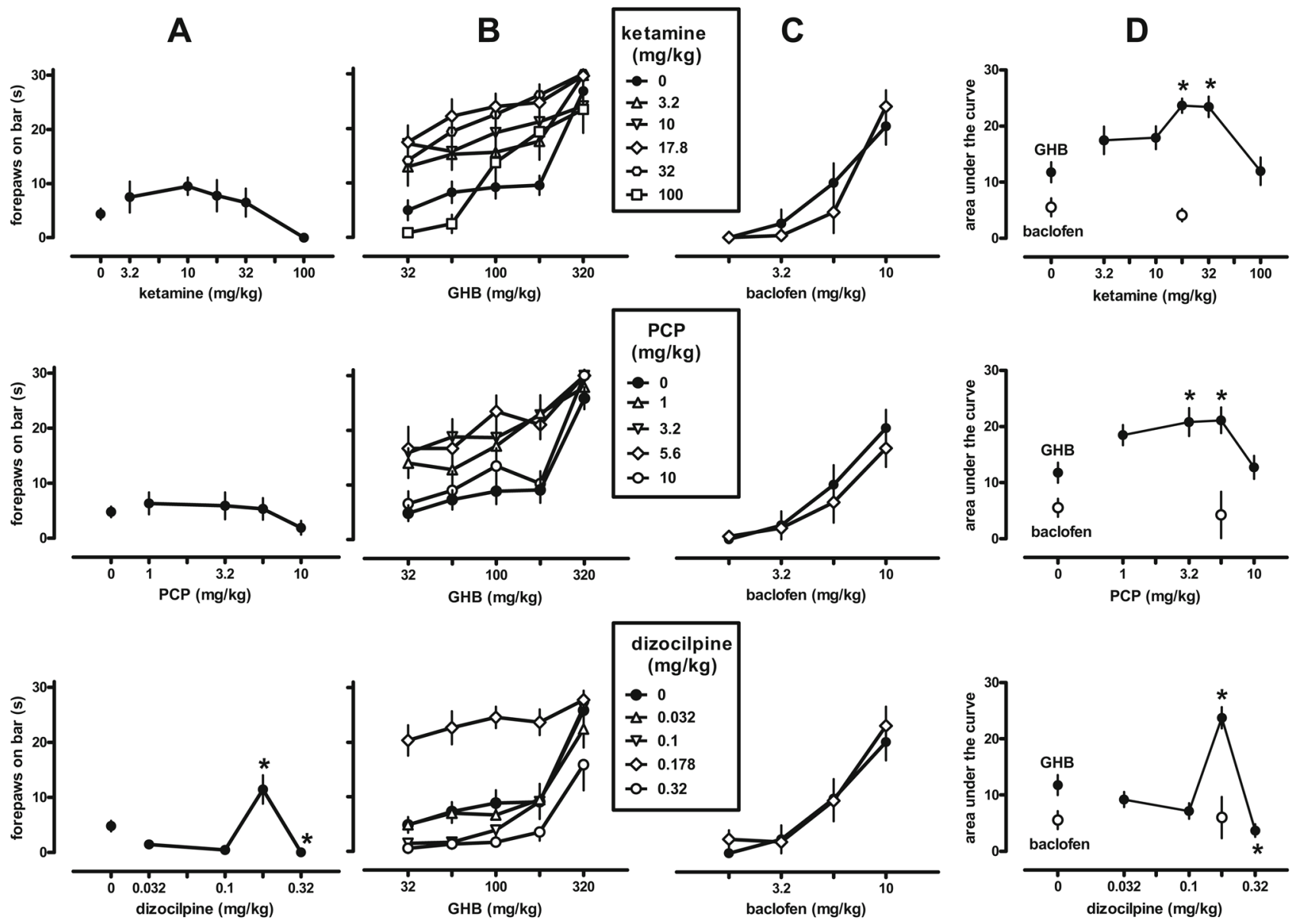

Fig. 1.

Cataleptic effects of cumulative doses of $\mathrm{GHB}$ and the $\mathrm{GABA}_{\mathrm{B}}$ receptor agonist baclofen after administration of saline or different doses of the NMDA antagonists ketamine, phencyclidine (PCP), or dizocilpine (MK-801) in C57BL/6J mice ( $n=8-13$ per dose, all injections i.p.). a Effects of the NMDA antagonists before the administration of GHB. $\mathbf{b}$ and c Effects of the NMDA antagonists on the dose-response curves of GHB and baclofen, respectively. d Effects of the NMDA antagonists on the area under the dose-response curves of GHB (filled symbols) and baclofen (open circles) shown in $\mathbf{b}$ and $\mathbf{c}$, respectively. Symbols represent mean \pm SEM; if not shown, SEM values are contained by the symbol. Asterisks $P<0.05$ (Dunnett's test vs control) 


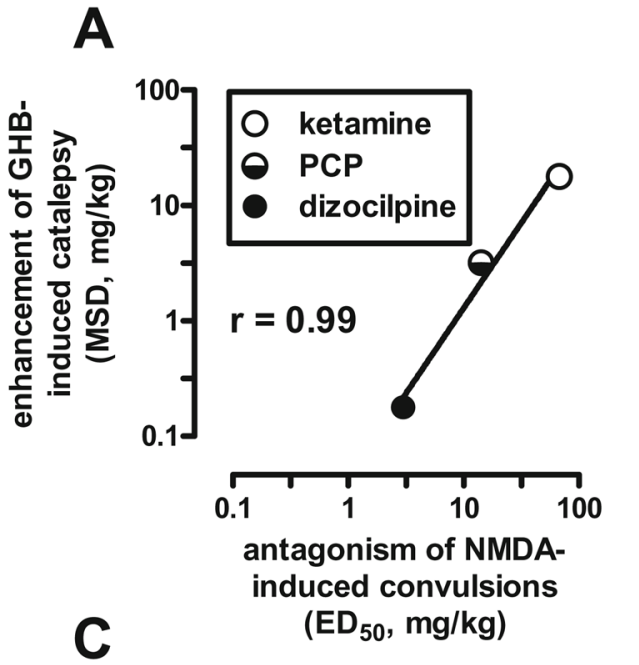

B
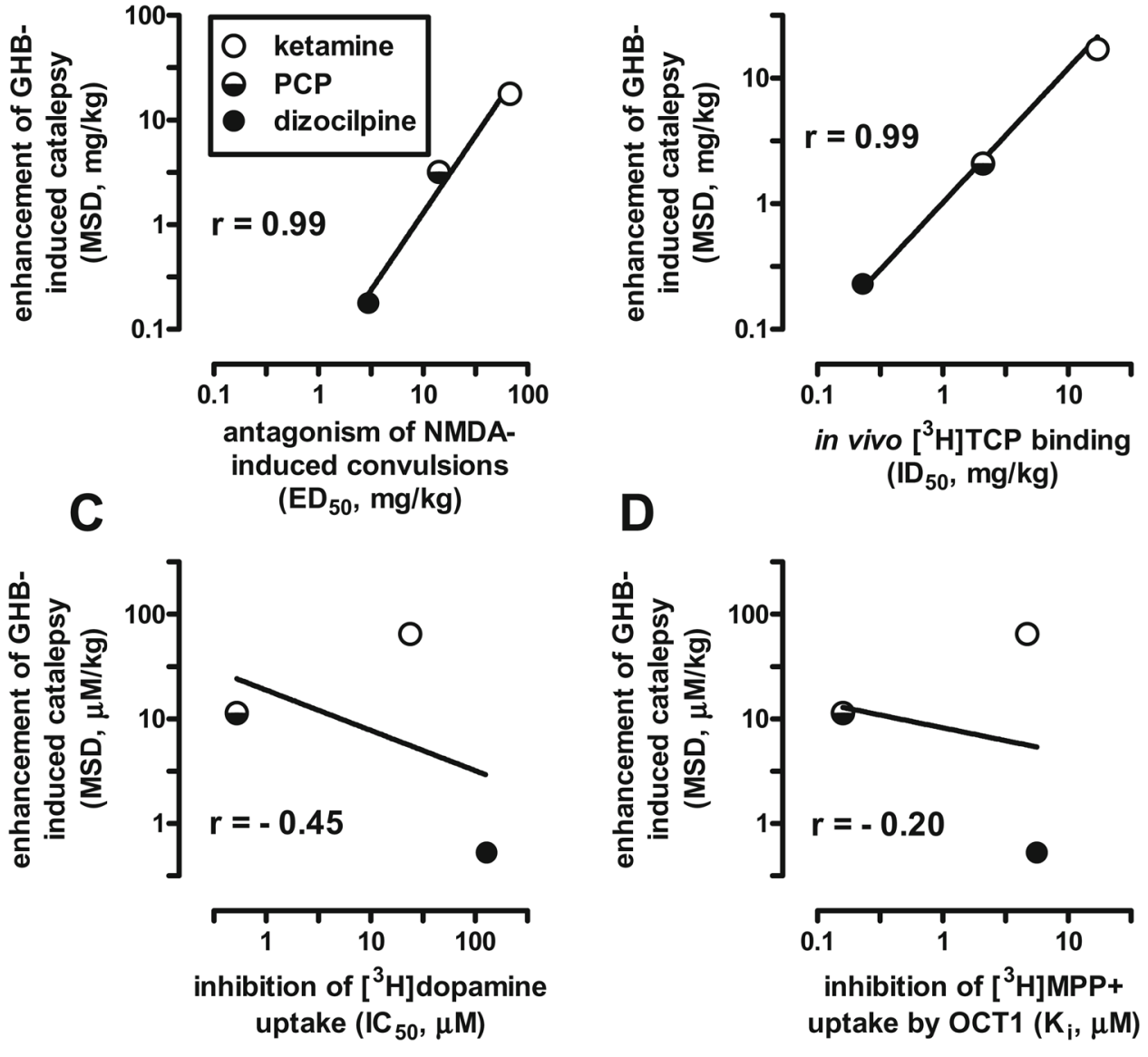

D

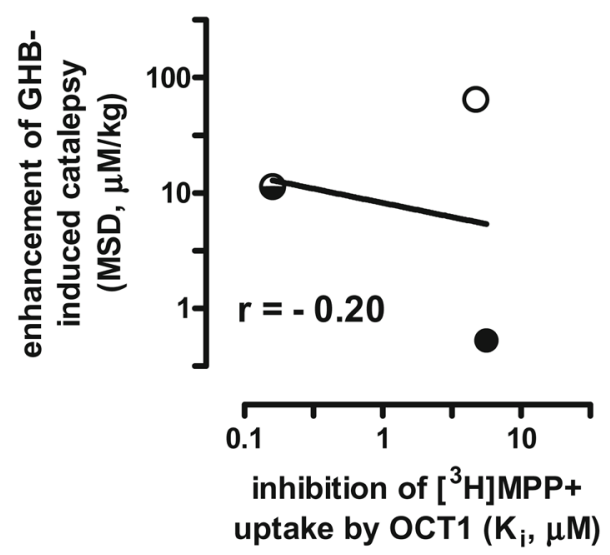

Fig. 2.

Relation between the potencies of the NMDA antagonists ketamine, phencyclidine (PCP), and dizocilpine (MK-801) to enhance GHB-induced catalepsy in mice and their potencies to a antagonize NMDA-induced convulsions in mice (Koek and Colpaert 1990), b inhibit in vivo labeling of the NMDA receptor-associated ion channel with the phencyclidine derivative $\left[{ }^{3} \mathrm{H}\right] \mathrm{TCP}$ in mouse brain, which correlates strongly $(r=0.93)$ with in vitro $\left[{ }^{3} \mathrm{H}\right] \mathrm{TCP}$ binding in rat brain (Maurice and Vignon 1990), $\mathbf{c}$ inhibit $\left[{ }^{3} \mathrm{H}\right]$ dopamine uptake into rat striatal synaptosomes (Johnson and Snell 1985; Snell et al. 1988), and d inhibit $\left[{ }^{3} \mathrm{H}\right] \mathrm{MPP}^{+}$uptake by rat organic cation transporter 1 (OCT1) in transfected HEK293 cells (Amphoux et al. 2006). MSD minimum significant dose, $r$ Pearson's correlation coefficient 